\title{
ECOLOGICAL PATTERNS IN STAPHYLINIDAE (INSECTA: COLEOPTERA) IN CROPPED AND FOREST AREAS OF THE PUNJAB, PAKISTAN
}

\author{
Shabab Nasir ${ }^{1, *}$, Waseem Akram² and Farooq Ahmed ${ }^{2}$ \\ ${ }^{1}$ Department of Zoology, Government College University, Faisalabad, Pakistan; \\ ${ }^{2}$ Department of Agri-Entomology, University of Agriculture, Faisalabad, Pakistan. \\ *Corresponding author's e-mail:flourenceshabab@yahoo.com
}

\begin{abstract}
The type of locality and seasons had a great effect on species composition (richness and abundance) and community structure of rove beetles. This was determined in 3 forest and 8 cultivated areas of the Punjab from January 2008 to December 2009. A total of 2,386 specimens belonging to 26 species were captured by using 5 different collection methods, i.e. pitfall traps, flight intercept trap, light trap, Berlese funnel trap and netting. Each area was sampled for four days with an interval of 2 months. The percentage population of different species and Shannon-Wiener diversity index was calculated. Maximum species richness and abundance was observed during rainy season (July-August). Even a single specimen of Paederus fuscipes Curt., Philonthus cinotulus Kr., Philonthus gemellus Kr., Myrmecopora elegans Cam., Tachyporus himalayicus Bernh., and Astilbus mixtus Cam. was not found from forest area during the whole period of collection.Overall, Paederus fuscipes was the species with the highest population (16.05\%), while Tachyporus himalayicus with the lowest $(0.22 \%)$. High $\alpha$-diversity index (20.804) and Shannon-Wiener (2.573) were found from Sargodha in 2008 and Gutwala in 2009.Their lowest values (9.76) and (1.82) respectively were found from Rawalpindi in 2008.

Keywords: Biodiversity, predator, forest area, insects, staphylinids
\end{abstract}

\section{INTRODUCTION}

Rove beetles (Staphylinidae) are a very successful group of insects, found in nearly all terrestrial habitats (Nasir and Akram, 2012). The tiny and slender body, with short elytra and movable abdominal segments, enable these beetles to inhibit and move in ecologically different habitats i.e. leaf litter and decaying animal wastes (Nasir et al., 2015). Many species have well developed wings and can move long distances. Their biodiversity is poorly known in most terrestrial ecosystems, in particular tropical ones (Chung et $a l ., 2000)$. They are found in a variety of habitats, i.e. under stones, under tree bark, near streams (Frank and Thomas, 2002), in leaf litter and in dung (Cameron, 1930; Koller et al., 2002). Osorius, Oxytelus, Philonthus, Staphylinus, Liphocharis, Platystethus, Tachinus and Creophilus are commonly found genera amongst these habitats (Newton, 1984, 1990). They also occur in nests of birds, ants, termites, and in fungi (Forsyth and Alcock, 1990). Species of the genera Oxyporus and Conosoma are mostly found attached to fungal spores and hyphae (Leschen and Allen, 1988). Due to the variety of habitats, these beetles act as detrivores, fungivores and parasites of dipterous pupae (Fournetet al., 2000). Staphylinds also act as predators of aphids (Collins et al., 2002), Collembolans, thrips, algae (Wyatt, 1993) and other fauna found in decaying organic matter (Good and Giller, 1991). Swarming rove beetles cause great trouble in the evening and annoyance by getting into human eyes resulting in severe irritation. Paederus fuscipes has been found to cause dermatitis in US troops in Afghanistan, Northern areas of Pakistan (Qadir et al., 2006), in India (Somerset, 1961) and in Iran (Nikbakhtzadeh and Tirgari, 2008). These species are well distributed in Pakistan (Nasir, 2011). Because of their flight, staphylinids have been found to disperse actively between natural and cultivated lands (Coombes and Sotherton, 1986) where they hibernate and reproduce (Sotherton, 1985). Thus, these factors influence species richness besides improving the numerical status (Purtauf et al., 2005). Forest ecosystem plays an important role in maintaining diversity and abundance of leaf litter staphylinids (Apigian et al., 2006). Due to their presence in a wide range of habitats and in most natural, semi-natural, and man-made habitats, they act as important bio-indicators (Kremen et al., 1993).

There is no doubt that a large number of species have been reported from the Indian Sub-continent including Ceylon and Burma (Cameron, 1930), but most species have been recorded from areas outside of Pakistan. Rehman and Ghani (1941) reported 133 species of rove beetles from pre-partition Punjab mentioned in the Fauna of British India, 131 species from hilly areas of Simla (India) and only 2 species from plains of Lahore (Pakistan) and Shahpur. This shows that these workers did not pay any serious attention at this part of the country. A lot of work has been done and must be continued in the future to explore the staphylinid fauna in the world but no attention has been paid on these insects in Pakistan except few 
references, which are reported from NWFP (Hlavac, 2006), Baluchistan and Sindh (Cameron, 1930; Abdullah and Qadri, 1968, 1970) and Punjab (Nasir, 2011). In this study, the ecological considerations, particularly species richness, evenness, abundance and phenology of Staphylinidae were studied with reference to environmental parameters for each site.

\section{MATERIALS AND METHODS}

This study on biodiversity of staphylinids was carried out in 2008 and 2009 in different areas of the Punjab, Pakistan. The project focused on collecting staphylinids from cultivated and forest areas by sifting of leaf litter, flight intercept trap (FIT), sweeping of grass, pitfall traps (Garcia and Chacon de ullea, 2005; Derunkov, 2007) and light traps. Punjab presents an extraordinary diversity of biological environments. In this study, eleven localities (Fig. 1) from different cropping areas and forests were selected. Using a Magellan GPS (Explorist 660), the positions and altitudes of each locality were recorded (Table 1).

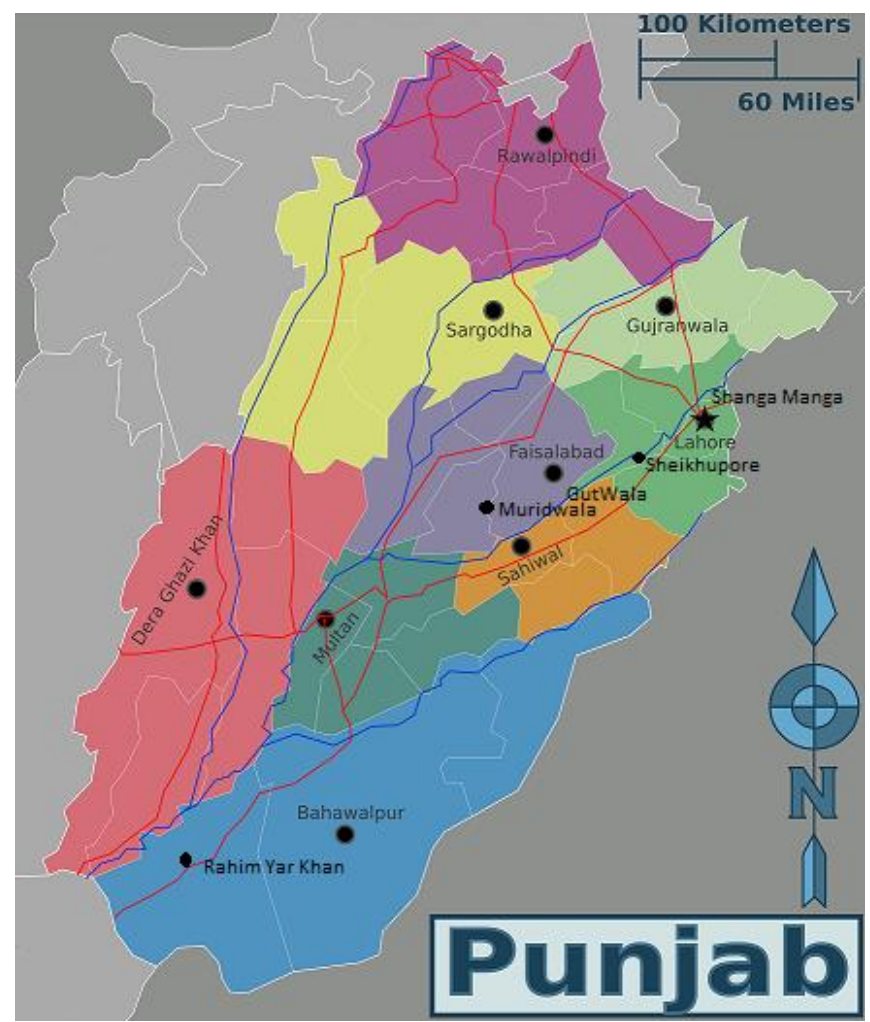

Figure 1. Map of the Punjab, Pakistan showing the sampling localities.

Site 1: Cultivated area (Lahore) at $194 \mathrm{~m}$ elevation mainly with wheat-vegetables, but maize and sugar cane is also grown on small scale. There are many gardens in this area. Irrigation is through tubewell, sewage water or canal water like other cultivated sites. This site is very close to site 2 and further from sites 5 and 8;

Table 1. GPS positions of the selected localities.

\begin{tabular}{llccc}
\hline $\begin{array}{l}\text { Plot } \\
\text { No. }\end{array}$ & Locality name & Latitude & Longitude & $\begin{array}{c}\text { Elevation } \\
(\mathbf{m})\end{array}$ \\
\hline 1 & Lahore & $31^{\circ} 14.287^{\prime}$ & $73^{\circ} 59.513^{\prime}$ & 194 \\
2 & Sheikhupur & $31^{\circ} 34.723^{\prime}$ & $73^{\circ} 29.117^{\prime}$ & 187 \\
3 & Faisalabad & $31^{\circ} 26.271^{\prime}$ & $73^{\circ} 04.699^{\prime}$ & 183 \\
4 & Multan & $30^{\circ} 12.534^{\prime}$ & $71^{\circ} 27.813^{\prime}$ & 104 \\
5 & Rahim Yar Khan & $28^{\circ} 26.450^{\prime}$ & $70^{\circ} 19.712^{\prime}$ & 83 \\
6 & Sargodha & $32^{\circ} 05.379^{\prime}$ & $72^{\circ} 40.566^{\prime}$ & 183 \\
7 & Rawalpindi & $33^{\circ} 34.425^{\prime}$ & $73^{\circ} 05.161^{\prime}$ & 496 \\
8 & D.G. Khan & $30^{\circ} 18.209^{\prime}$ & $70^{\circ} 43.324^{\prime}$ & 117 \\
9 & Changa Manga & $31^{\circ} 04.729^{\prime}$ & $73^{\circ} 59.967^{\prime}$ & 196 \\
10 & Gutwala & $31^{\circ} 28.254^{\prime}$ & $73^{\circ} 12.291^{\prime}$ & 185 \\
11 & Muridwala & $30^{\circ} 72.03^{\prime}$ & $72^{\circ} 45.65^{\prime}$ & 150 \\
\hline
\end{tabular}

Site 2: Cultivated area (Sheikhupur) at $187 \mathrm{~m}$ elevation with wheat-rice cropping pattern, but people also grow vegetables, maize and sugar cane for their own use. Tubewell and canal water is used for irrigation similar to sites $1,3,4,5$, and 6;

Site 3: Cultivated area (Faisalabad) at $183 \mathrm{~m}$ elevation with a cropping pattern similar to site 1, but lacked gardens. Sewage, canal and tube well water is used for irrigation. This area is very close to sites 2,6 , and 10 and its soil is mostly of clay and loam similar to sites 1 and 2;

Site 4: Cultivated area (Multan) at 104 m elevation with cotton and mango growing area of the Punjab. Cropping pattern in this area is wheat-cotton similar to sites 5 and 8 with heavy use of pesticides. Some sandy soils were also present similar to sites 5 and 8 ;

Site 5: Cultivated area (Rahim Yar Khan) at $83 \mathrm{~m}$ elevation with similar cropping pattern as in site 4 , but without mango gardens. Soil is mostly sandy where date plantation and sand dunes are present;

Site 6: Cultivated area (Sargodha) at 183 m elevation famous for its citrus gardens. Normal cropping pattern is wheat-rice or wheat-sugar cane. The area is hilly with mostly clay soil. People use farm yard manures to increase fertility of the soil as in other sites in the Punjab. Source of irrigation is tubewell and canal water.

Site 7: Cultivated area (Rawalpindi) at $496 \mathrm{~m}$ elevation with barani area. Mostly, people use rainfall for irrigation but tubewell water is also used for irrigation purposes. Mostly, people grow wheat and grams. Hilly areas are also present in this site;

Site 8: Cultivated area (Dera Ghazi Khan) at 117 m elevation with cropping pattern similar to sites 4 and 5. Use of pesticides is common due to cotton plantation. People depend mostly on rainfall and tubewell water for irrigation, but few areas have canal water due to newly built canals. Bushy plantation and hills are present with sandy soil; 
Site 9: Forest area (Changa Manga) at $196 \mathrm{~m}$ elevation with the largest man made eucalyptus plantations in the Punjab. This site is very close to site 1 . For irrigation purposes, canals are built similar to other forest sites. This is the mostly disturbed area similar to site 10 because people use it for vacation;

Site 10: Forest area (Gutwala) at $185 \mathrm{~m}$ elevation with manmade eucalyptus plantation, a park for recreation, and a small zoo close to site 3.Soil is made of sand and clay. Rainfall and canal water is used for irrigation purposes and people mostly grow vegetables;

Site 11: Forest area (Muridwala) at $150 \mathrm{~m}$ elevation with another man made forest of a mixed type of plantation.

Sampling of the staphylinid fauna was performed from January to December in one plot from each cultivated and forest area in 2008 and 2009 (Table 2). The traps were installed for four days in each locality every second month. The samples were brought to the Biodiversity Laboratory in the Department of Entomology, University of Agriculture, Faisalabad. Standard techniques for preserving and mounting included clearing in $10 \% \mathrm{KOH}$. Later, the specimens were treated with glacial acetic acid and dehydrated in ascending grades of alcohol and mounted in Hoyer's medium. The material was sorted and identified under the microscope using the keys by Cameron (1930). Other keys (Shafi, 1957; Scheerpeltz, 1960; Abdullah and Qadri, 1970; Coiffait, 1982, 1984; Pace, 1986; Lobl, 1986; Herman, 2001; Smetana, 2004), web sites and entomological articles were also used to identify the specimens.

Analysis of Data: The dominance of each species was determined and Shannon diversity and evenness were calculated using natural logarithm (Shannon-Wiener, 1949; Silveria Neto et al., 1976; Pielou, 1984).

\section{Table 2. Timetable of the studied plots.}

\begin{tabular}{|c|c|}
\hline Dates & Locality \\
\hline During first week of first month & Faisalabad and Gutwala \\
\hline $\begin{array}{l}\text { During second and third week of } \\
\text { first month }\end{array}$ & $\begin{array}{l}\text { Lahore, Changa Manga } \\
\text { and Sheikhupur }\end{array}$ \\
\hline $\begin{array}{l}\text { During fourth week of first } \\
\text { month }\end{array}$ & $\begin{array}{l}\text { Sargodha and } \\
\text { Rawalpindi }\end{array}$ \\
\hline $\begin{array}{l}\text { During first week of second } \\
\text { month }\end{array}$ & Muridwala \\
\hline $\begin{array}{l}\text { During second and third week of } \\
\text { second month }\end{array}$ & $\begin{array}{l}\text { Multan and Dera Ghazi } \\
\text { Khan }\end{array}$ \\
\hline $\begin{array}{l}\text { During fourth week of second } \\
\text { month }\end{array}$ & Rahim Yar Khan \\
\hline
\end{tabular}

\section{RESULTS}

Environmental temperature variation: The temperature, relative humidity, and soil moisture data were taken from meteorological stations close to the sampling sites. It is reasonable to assume that the data taken in the field are not really sufficient to assess these factors, but may provide a general indication of preferences (Marquez, 2003). All the selected sites had a similar temperature range (Table 3 ). The highest temperature was measured at site 7 (cultivated non irrigated area) followed by site 8 (cultivated irrigated area), i.e. $35^{\circ} \mathrm{C}$ and $34.6^{\circ} \mathrm{C}$ respectively. The highest temperature variation of $21.7^{\circ} \mathrm{C}$ was recorded at site $1\left(12.3\right.$ to $\left.34^{\circ} \mathrm{C}\right)$ and the smallest variation with $18.8^{\circ} \mathrm{C}$ was at site 11 (15 to $33.9^{\circ} \mathrm{C}$ ). All the other sites showed intermediate conditions between them (Table 3).

Relative humidity variations: Relative humidity variance was similar at all selected sites. During the rainy season (July to September), the relative humidity was high and during the dry season (November to May) it was low. The lowest value of relative humidity (R.H.) was recorded from site $8(26 \%)$ from May-June during late dry season. The highest R.H (\%) was recorded from site $3(65.4 \%)$ from July-August. Site 3 had the greatest $\mathrm{RH}$ variance by $32.9 \%$, i.e., from 32.5 to $65.4 \%$ (Table 3).

Soil moisture contents: Soil moisture variance was similar at all selected sites. During the rainy season (July to September), the soil moisture was high and during the dry season (November to May), it was low. The lowest value of soil moisture was recorded from site $10(16 \%)$ from NovemberDecember during the middle of the dry season. The highest value was recorded from site 1 (58\%) from July-August. Site 1 had the highest soil moisture variance by $12.4 \%$, i.e., from 45.6 to $58 \%$ (Table 3 ).

Species richness: A total of 2,386 specimens were collected in 2008 and 2009 belonging to 5 subfamilies, 15 genera, and 26 species. All specimens were identified to species level. Staphylininae was the subfamily with the highest number of species (8), followed by Paederinae (7), Aleocharinae (5), Oxytelinae (4) and Tachyporinae (2). The highest number of species was collected from site 3 (22).In regards to species richness, both sites 6 and 1 were very close to site 3 with 21 and 20 species respectively. Site 7 was the site with the lowest number of species (12). The sites with higher number of species were all cultivated and irrigated sites that provided more resources for staphylinids to live than other sites such as barani (rain fed areas) or forest sites (that were also not irrigated regularly). The sites with high use of insecticides provided lower number of species than sites without insecticides use.

Abundance: Paederinae, Staphylininae, Oxytelinae, Aleocharinae, and Tachyporinae account for 51, 25, 13, 8, and $3 \%$ of total amount of specimens, respectively.Sites 6, 3, 1 and 2 each, and 10 accounted for 12.7, 12.70, 11.43, and $5.29 \%$ of total specimens.Paederus fuscipes accounted for the highest number of specimens from cropped areas but none from forest areas. Philonthus delicatulus was the species with the highest number of specimens from the forest areas. Overall, Paederus fuscipes was the most abundant species 
Nasir, Akram \& Ahmed

Table 3. Record of temperature, Relative humidity and soil moisture contents by months and sites.

\begin{tabular}{|c|c|c|c|c|c|c|c|c|c|c|c|c|}
\hline \multirow[t]{2}{*}{ Months } & \multicolumn{2}{|c|}{ Jan/Feb } & \multicolumn{2}{|c|}{ Mar/Apr } & \multicolumn{2}{|c|}{ May/Jun } & \multicolumn{2}{|c|}{ Jul/Aug } & \multicolumn{2}{|c|}{ Sep/Oct } & \multicolumn{2}{|c|}{ Nov/Dec } \\
\hline & 2008 & 2009 & 2008 & 2009 & 2008 & 2009 & 2008 & 2009 & 2008 & 2009 & 2008 & 2009 \\
\hline \multicolumn{13}{|l|}{ LHR/194m } \\
\hline Temperature $\left({ }^{\circ} \mathrm{C}\right)$ & 12.3 & 15 & 25 & 24 & 33.4 & 34 & 32.2 & 30 & 28 & 28.9 & 18 & 19.1 \\
\hline R.H $(\%)$ & 29.7 & 31.3 & 32.4 & 35.6 & 31 & 32.8 & 55 & 60.3 & 51.2 & 53 & 32.3 & 31 \\
\hline S.M.C (\%) & 47 & 45.6 & 52 & 51 & 51 & 49.5 & 58 & 56.8 & 53 & 52 & 48 & 49 \\
\hline \multicolumn{13}{|l|}{$\mathrm{SHP} / 187 \mathrm{~m}$} \\
\hline Temperature $\left({ }^{\circ} \mathrm{C}\right)$ & 12.2 & 14.3 & 24.7 & 23.8 & 33.1 & 33.7 & 32 & 32.6 & 27.3 & 28.5 & 17.2 & 19.1 \\
\hline R.H $(\%)$ & 34 & 32.4 & 36.4 & 38 & 32.8 & 36.2 & 52.6 & 53.1 & 43.6 & 41.8 & 30 & 35.3 \\
\hline S.M.C (\%) & 45.3 & 46 & 48 & 47.4 & 49.6 & 48.8 & 56 & 55.1 & 52 & 51.2 & 48.6 & 46 \\
\hline \multicolumn{13}{|l|}{ FSD/ $183 \mathrm{~m}$} \\
\hline Temperature $\left({ }^{\circ} \mathrm{C}\right)$ & 12.7 & 14.8 & 24.3 & 23.5 & 31.8 & 33.1 & 31.9 & 32.5 & 27.8 & 28.5 & 17.6 & 18 \\
\hline R.H $(\%)$ & 39.2 & 56.2 & 42 & 47.6 & 39.1 & 32.5 & 65.4 & 65.4 & 58.4 & 59 & 55.4 & 44.3 \\
\hline S.M.C (\%) & 46 & 45.2 & 48.2 & 49 & 48.7 & 48.7 & 52 & 51.6 & 51.2 & 49.1 & 48 & 47.6 \\
\hline \multicolumn{13}{|l|}{$\mathrm{MTN} / 104 \mathrm{~m}$} \\
\hline Temperature $\left({ }^{\circ} \mathrm{C}\right)$ & 14.3 & 16 & 25.9 & 24.9 & 33 & 34.5 & 33.5 & 34.1 & 29.3 & 30 & 19 & 19.7 \\
\hline R.H $(\%)$ & 60 & 49.2 & 53.4 & 47 & 43 & 45.2 & 62.9 & 57.3 & 50.1 & 48.7 & 51.4 & 39.6 \\
\hline S.M.C (\%) & 38.7 & 37.1 & 39 & 38.5 & 39.6 & 39 & 45.8 & 42.6 & 42 & 39.6 & 40.2 & 36 \\
\hline \multicolumn{13}{|l|}{$\mathrm{RYK} / 83 \mathrm{~m}$} \\
\hline Temperature $\left({ }^{\circ} \mathrm{C}\right)$ & 13.8 & 14.4 & 24.4 & 24.9 & 32.3 & 33 & 32.9 & 33.3 & 28.1 & 28.9 & 17.7 & 18.2 \\
\hline R.H $(\%)$ & 46.3 & 43.7 & 45 & 46 & 39.5 & 40.2 & 53.7 & 56 & 47 & 42 & 37.6 & 39.3 \\
\hline S.M.C (\%) & 35 & 34.2 & 37.1 & 35.6 & 36 & 36 & 42 & 43.2 & 40.4 & 40.6 & 34 & 34.8 \\
\hline \multicolumn{13}{|l|}{$\mathrm{SGD} / 183 \mathrm{~m}$} \\
\hline Temperature $\left({ }^{\circ} \mathrm{C}\right)$ & 12.5 & 12.8 & 23.9 & 24 & 31.4 & 32 & 31.5 & 31.5 & 27.1 & 27.4 & 17.3 & 17.6 \\
\hline R.H $(\%)$ & 36 & 38.4 & 42.1 & 43 & 40 & 41.3 & 59 & 58.4 & 42 & 49.1 & 37.8 & 34.9 \\
\hline S.M.C (\%) & 28.6 & 29.4 & 32.5 & 34.1 & 34.8 & 34.2 & 45.2 & 45.3 & 40 & 38.9 & 33.3 & 32.8 \\
\hline \multicolumn{13}{|l|}{ RWP/496m } \\
\hline Temperature $\left({ }^{\circ} \mathrm{C}\right)$ & 16 & 18.1 & 25.3 & 24.6 & 34.4 & 35 & 30.2 & 34 & 28 & 26.3 & 19 & 17.3 \\
\hline R.H $(\%)$ & 56 & 52 & 48 & 46.9 & 35 & 45 & 56 & 56 & 47.9 & 45.8 & 38.7 & 37.3 \\
\hline S.M.C (\%) & 26 & 27.2 & 30.1 & 32.2 & 30 & 30.5 & 36.7 & 35.6 & 35 & 31 & 30 & 29.4 \\
\hline \multicolumn{13}{|l|}{$\mathrm{DGK} / 117 \mathrm{~m}$} \\
\hline Temperature & 15.7 & 10.4 & 24.5 & 24.4 & 34.4 & 34.6 & 34.2 & 34.3 & 30 & 30.1 & 19.3 & 19.4 \\
\hline R.H (\%) & 35 & 35.6 & 28 & 34 & 26 & 30.1 & 49.5 & 50 & 42.1 & 43.4 & 32.4 & 37.5 \\
\hline S.M.C $(\%)$ & 27 & 25.8 & 32.2 & 29.6 & 31.5 & 30 & 34.6 & 34.8 & 39.2 & 32 & 29.8 & 30.1 \\
\hline \multicolumn{13}{|l|}{$\mathrm{CNG} / 196 \mathrm{~m}$} \\
\hline Temperature $\left({ }^{\circ} \mathrm{C}\right)$ & 12.5 & 15.1 & 25.3 & 24.3 & 33.6 & 34.2 & 32.6 & 33.3 & 28.3 & 29 & 18.2 & 19.4 \\
\hline R.H $(\%)$ & 30.1 & 32.9 & 34.3 & 32 & 32 & 31.5 & 51.6 & 51 & 45 & 46.7 & 30.3 & 30 \\
\hline S.M.C (\%) & 25.3 & 25.3 & 26 & 26 & 25.4 & 25.4 & 32.6 & 32.6 & 30 & 30 & 29.8 & 29.8 \\
\hline \multicolumn{13}{|l|}{ GTW/185m } \\
\hline Temperature & 13 & 15 & 24.6 & 23.9 & 32.2 & 33.5 & 32.5 & 32.9 & 28 & 29 & 17.9 & 18.6 \\
\hline R.H (\%) & 29.1 & 38.4 & 41.3 & 42 & 38.5 & 36 & 57 & 58.7 & 27 & 51.6 & 48.3 & 36.6 \\
\hline S.M.C (\%) & 23 & 23.1 & 25 & 24.5 & 23 & 24 & 28 & 30 & 19 & 28 & 16 & 23 \\
\hline \multicolumn{13}{|l|}{$\mathrm{MDW} / 150 \mathrm{~m}$} \\
\hline Temperature $\left({ }^{\circ} \mathrm{C}\right)$ & 15.1 & 15.3 & 23.9 & 23.7 & 33.6 & 33.9 & 32.9 & 33.5 & 29.4 & 30.1 & 18.8 & 19 \\
\hline R.H $(\%)$ & 35 & 34.8 & 43.3 & 42 & 38.9 & 36.7 & 53.9 & 51.8 & 47 & 43.7 & 38 & 36 \\
\hline S.M.C (\%) & 24.2 & 23.6 & 25 & 25.2 & 24.6 & 24.6 & 30 & 30.2 & 28.6 & 28.1 & 23.8 & 23 \\
\hline
\end{tabular}

with $16.05 \%$ specimens followed by Philonthus delicatulus with $11.8 \%$ specimens. Tachyporus himalayicus was the species with the least $(0.22 \%)$ abundance (Table 4$)$.

Diversity: In 2008, the highest value of the Shannon diversity index (2.572) was found in site 5 (Rahim Yar Khan) and the lowest (1.82) at site 7 (Rawalpindi). The other localities showed intermediate values. The highest evenness (0.891) was recorded from site 8 (Dera Ghazi Khan), while low from (Lahore) site 1 (0.696). The highest dominance was 0.304 in this locality (Table 5). In 2009, the highest Shannon diversity index (2.534) was found at site 6 (Sargodha), the lowest (1.97) at site 7 (Rawalpindi) while other localities were intermediate. 
Table 4. List of species in percentage (\%) of staphylinid beetles collected from cropped and forest areas of the Punjab, Pakistan in 2008 and 2009.

\begin{tabular}{lccccc}
\hline Species & $\begin{array}{c}\text { Cropped } \\
\mathbf{2 0 0 8}(\mathbf{\%})\end{array}$ & $\begin{array}{c}\text { Area } \\
\mathbf{2 0 0 9}(\mathbf{\%})\end{array}$ & $\begin{array}{c}\text { Forest } \\
\mathbf{2 0 0 8}(\mathbf{\%})\end{array}$ & $\begin{array}{c}\text { Area } \\
\mathbf{2 0 0 9}(\mathbf{\%})\end{array}$ & $\begin{array}{c}\text { Overall } \\
(\mathbf{\%})\end{array}$ \\
\hline Oxytelus ferrugineus & 2.60 & 3.30 & 1.85 & 1.98 & 2.43 \\
Oxytelus sordidus & 5.00 & 5.00 & 2.96 & 1.32 & 3.57 \\
Oxytelus varipennis & 5.10 & 6.20 & 2.59 & 1.51 & 3.88 \\
Platystethus cornutus & 1.40 & 1.70 & 1.11 & 0.66 & 1.22 \\
Paederus fuscipes & 33.60 & 30.60 & 0.00 & 0.00 & 16.05 \\
Paederus tumulus & 5.30 & 6.00 & 4.20 & 6.62 & 5.33 \\
Paederus pubescens & 8.20 & 7.50 & 0.40 & 0.33 & 4.11 \\
Paederus basalis & 5.20 & 4.90 & 9.20 & 10.92 & 7.55 \\
Stilicus ceylanesis & 3.01 & 3.70 & 5.19 & 4.64 & 4.13 \\
Astenus sp. & 1.41 & 1.10 & 8.52 & 6.95 & 4.51 \\
Cryptobium abdominalis & 2.00 & 1.80 & 0.00 & 0.66 & 1.11 \\
Philonthus delicatulus & 4.61 & 5.90 & 17.78 & 18.87 & 11.80 \\
Philonthus cinotulus & 2.40 & 3.00 & 0.00 & 0.00 & 1.35 \\
Philonthus gemellus & 1.50 & 1.70 & 0.00 & 0.00 & 0.80 \\
Philonthus minutes & 1.50 & 1.40 & 6.67 & 5.30 & 3.72 \\
Leptacinus parumpunctatus & 2.30 & 1.80 & 11.48 & 9.27 & 6.21 \\
Staphylinus sp. & 1.90 & 1.71 & 4.81 & 5.63 & 3.51 \\
Aleochara clavicornis & 1.70 & 2.60 & 4.81 & 4.97 & 3.52 \\
Aleochara puberula & 1.20 & 1.51 & 0.00 & 0.66 & 0.84 \\
Myrmecopora elegans & 1.90 & 1.60 & 0.00 & 0.00 & 0.90 \\
Tachyporus himalayicus & 0.51 & 0.40 & 0.00 & 0.00 & 0.22 \\
Tachinomorphus ceylonicus & 0.80 & 1.10 & 6.75 & 6.67 & 3.83 \\
Philonthus thermarum & 0.90 & 0.90 & 6.50 & 9.27 & 4.39 \\
Aleochara sp. & 1.71 & 1.20 & 0.00 & 0.00 & 0.72 \\
Platyprosopis sp. & 1.60 & 1.41 & 4.81 & 3.64 & 2.86 \\
Astilbus mixtus & 2.90 & 2.11 & 0.00 & 0.00 & 1.25 \\
\hline
\end{tabular}

Table 5. Richness measures of Staphylinids in the cropped and forest areas of the Punjab, Pakistan.

\begin{tabular}{|c|c|c|c|c|c|c|c|c|}
\hline \multirow{2}{*}{ Localities } & \multicolumn{3}{|c|}{2008} & \multicolumn{5}{|c|}{2009} \\
\hline & $\left(\mathbf{H}^{\prime}\right)$ & $\left(\mathbf{J}^{\prime}\right)$ & (D) & $\alpha$ & $\left(\mathbf{H}^{\prime}\right)$ & $\left(\mathbf{J}^{\prime}\right)$ & (D) & $\alpha$ \\
\hline LHR & 1.838 & 0.696 & 0.304 & 13.794 & 2.5 & 0.835 & 0.165 & 19.801 \\
\hline SHP & 2.396 & 0.846 & 0.154 & 16.798 & 2.416 & 0.853 & 0.147 & 16.795 \\
\hline FSD & 2.388 & 0.784 & 0.216 & 20.799 & 2.419 & 0.795 & 0.205 & 20.801 \\
\hline MTN & 2.551 & 0.866 & 0.134 & 18.766 & 2.495 & 0.863 & 0.137 & 17.772 \\
\hline RYK & 2.572 & 0.890 & 0.110 & 17.773 & 2.459 & 0.835 & 0.165 & 18.778 \\
\hline SGD & 2.504 & 0.822 & 0.178 & 20.804 & 2.534 & 0.832 & 0.168 & 20.798 \\
\hline RWP & 1.820 & 0.790 & 0.210 & 09.760 & 1.970 & 0.793 & 0.207 & 11.770 \\
\hline CNG & 2.524 & 0.91 & 0.090 & 15.793 & 2.523 & 0.910 & 0.090 & 15.780 \\
\hline GTW & 2.427 & 0.875 & 0.125 & 15.737 & 2.573 & 0.874 & 0.126 & 18.772 \\
\hline MDW & 2.463 & 0.869 & 0.131 & 16.782 & 2.470 & 0.891 & 0.109 & 15.789 \\
\hline
\end{tabular}

$\mathrm{H}^{\prime}=$ Shanon diversity; $\mathrm{J}^{\prime}=$ Evenness; $\mathrm{D}=$ Dominance; $\alpha=$ Diversity index; LHR = Lahore; SHP = Sheikhupur; FSD = Faisalabad; MTN = Multan; RYK = Rahim Yar Khan; SGD = Sargodha; RWP = Rawalpindi; DGK = Dera Ghazi Khan; $\mathrm{CNG}=$ Changa Manga; GTW $=$ Gutwala; $\mathrm{MDW}=$ Murid Wala

The highest evenness (0.863) was recorded from site 4 (Multan), low (0.793) in site 7 (Rawalpindi), and also with the highest dominance (0.207) in this locality. Generally, the value of $\alpha$-diversity index was higher in 2009 than 2008. The values of Shannon-Wiener diversity index for different localities were slightly higher in 2008 than 2009, while the dominance was higher in 2009 (Table 5). Shannon diversity $\left(\mathrm{H}^{\prime}\right)$ refers to both species richness and abundance.

Species distribution: $\quad$ Some species such as Paederus fuscipes, Philonthus cinotulus, Philonthus gemellus, 
Myrmecopora elegans, Tachyporus himalyicus and Astilbus mixitus were found exclusively in cropping areas. No species was found to be in the site exclusive, but some species were found only in cropped areas and some were found to be confined up to forest areas only.

Phenology: Some species were found to be associated with some crops such as Paederus fuscipes that was collected mostly from maize (may be due to more aphids) and berseem or with cropping patterns. Some were found to be associated with humus (organic matter) in the soil but all species were found to be dependent on moisture contents in the soil. The highest number of species and their abundances were collected during the rainy season (July-August) except site 10 where the highest number of specimens was collected from March-April (Fig. 2).
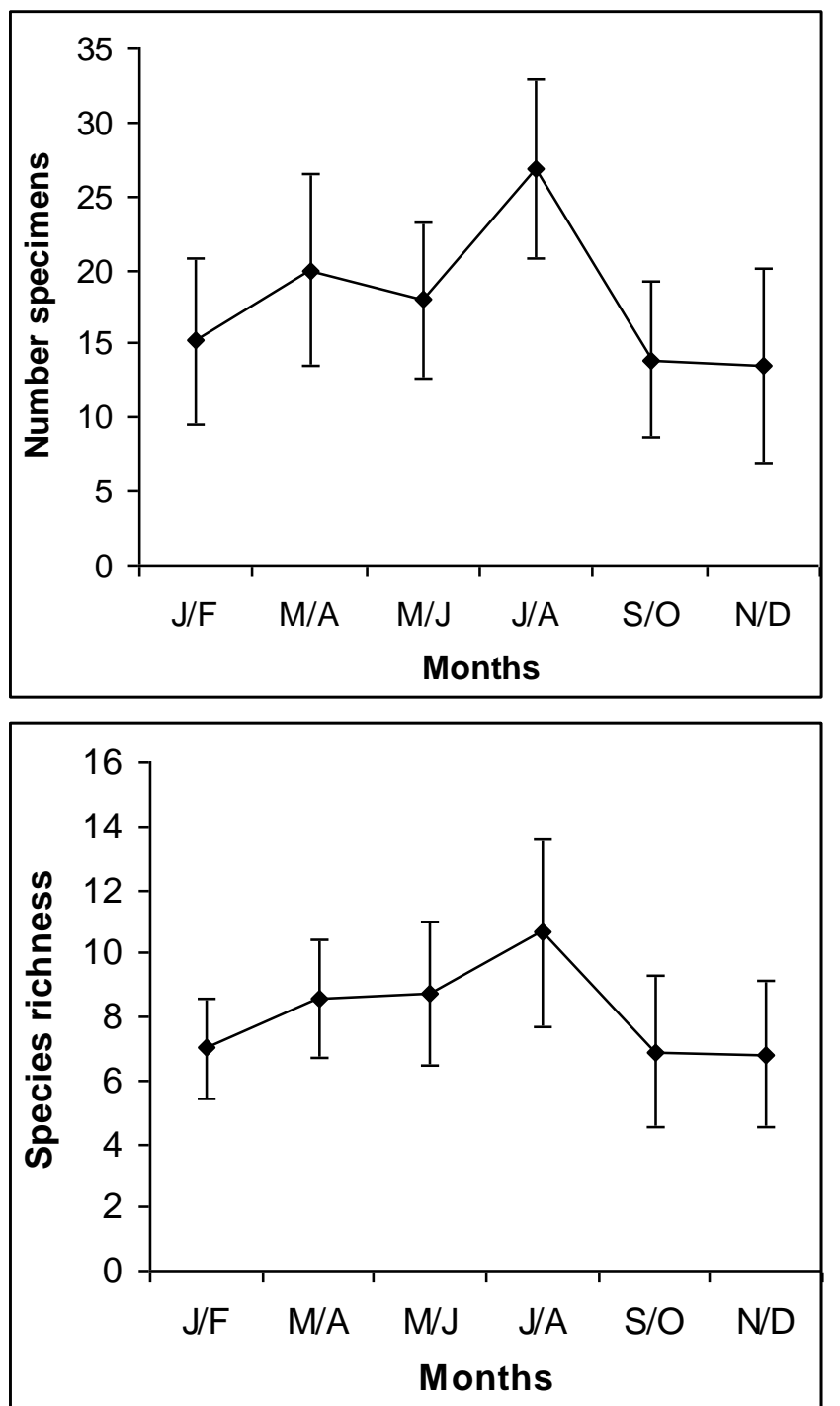

Figure 2. Species richness during different months of 2008 and 2009.
Some places had similar temperature and soil moisture but different number of specimens which was due to different crops and their sowing and harvesting time (Table 6) or other biotic factors such as prey availability or fewer disturbances.

Table 6. General sowing and harvesting periods of different crops in the Punjab, Pakistan.

\begin{tabular}{|c|c|c|c|}
\hline Crop & $\begin{array}{l}\text { General Sowing } \\
\text { period }\end{array}$ & $\begin{array}{l}\text { Harvesting } \\
\text { period }\end{array}$ & $\begin{array}{l}\text { Duration } \\
\text { of crop }\end{array}$ \\
\hline Wheat & Nov. to Dec. & April & 160 days \\
\hline Maize & Feb. and Jul. & May and Oct. & 100 days \\
\hline Cotton & End of Apr. to Jun. & Nov. & 180 days \\
\hline Rice & May to Jun. & Oct. & 150 days \\
\hline Berseem & Oct. & Mar. & 180 days \\
\hline $\begin{array}{l}\text { Summer } \\
\text { vegetables }\end{array}$ & Feb. to Mar. & Jun. to Jul. & 120 days \\
\hline $\begin{array}{l}\text { Winter } \\
\text { vegetables }\end{array}$ & Sep. to Oct. & Dec. to Jan. & 120 days \\
\hline
\end{tabular}

\section{DISCUSSION}

There was a serious need of information about the most essential aspects of biodiversity of staphylinid beetles in cropped and forest areas of Pakistan, particularly the number of species present. Information on beetle's diversity in the Punjab was generally available for many habitat types, but the information on the most diversified group of insects, i.e. rove beetles, was lacking. This is the first study on rove beetle biodiversity in the Punjab, and one of only a few studies in Pakistan to account for richness of staphylinids. Although a high richness of staphylinid species was found, it was evident that we had sampled only a small portion of the total staphylinid diversity in cropped and forest areas of the Punjab.

Staphylinid biodiversity: The main part of this study was to provide an estimate of the staphylinid diversity of the Punjab, Pakistan. In 2008 and 2009, the eleven selected sites were sampled for 730 days, with five different collecting methods. From these collecting methods, 5 sub-families, 16 genera, 26 species and 2,386 specimens were collected in 2008 and 2009. In these 11 sites, 8 were from cropped areas and 3 from forest areas. Although the traps were installed for only four days during each visit in every second month at each locality, the results indicated a low diversity and amedium abundance of staphylinids. Few species were found in large numbers (Paederus fuscipes, Philonthus delicatulus, Paederus pubescens, Paederus basalis and Paederus tamulus) and only one species was found with very low numbers (Tachyporus himalyicus). Although the frequency relation between species was interesting, this value must be interpreted with care, because it largely depends upon the efficiency of traps. No other study in the Punjab, Pakistan was conducted to compare our work with other scientists in the world.Similar results were found in Mexico by some scientists (Huacuja, 1982; 


\section{Ecological notes of rove beetles}

Ruiz-Lizarraga, 1993; Marquez, 2003; Abbas et al., 2014). They also found that the subfamily Staphylininae had the highest number of species as we did.

As indicated from the results, the traps efficiency was very unequal, because intercept traps and attractive traps were used together. Mostly specimens were caught with pitfall traps followed by Berlese funnel. Least numbers were caught with flight intercept and light traps. As some species were not attracted by traps, sweep nets and hand collections were used to enrich the collections. Shannon-Wiener index ( $\left.\mathrm{H}^{\prime}\right)$ and Simpson's index (D) are the two diversity measures that are theoretically independent of sample size. But these indices should be implemented with caution, because they are relatively insensitive to climatic influence compared with $\alpha$, that negatively affected by small sample, species dominance and presence of rare species (Taylor et al., 1976; Dritschilo and Erwin, 1982; Ludwig and Reynolds, 1988; Tonhasca, 1993). These indices are sensitive to the changes in the species abundance of the dominant species in a sample while the $\alpha$ index mainly deals with the species that are in between the species frequency distribution. Due to this, $\alpha$ is less influenced by one or two very abundant species (Taylor, 1978; Kempton, 1979). Because $\alpha$ mostly depends on species abundance in compliance to a log-series frequency allocation. Shannon-Wiener $\left(\mathrm{H}^{\prime}\right)$ index and $\alpha$ index were calculated from data in the present research work for comparison with other works and Simpsons' index was not calculated. In this study, H' was generally found between 1.9-2.5, while Shah et al. (2003) found it to be less than 2.0. Lubke (1991) reported that H' varied from 2.2 to 2.4 in wheat fields and Kromp and Steinberger (1992) reported a value of 4.1 from wheat in Australia. Dritschilo and Wanner (1980) reported that H' varied from 1.3-2.3 in maize fields and 1.3-1.7 from conventional fields. However, any idea from this discussion should be treated with caution because of poor practical performance of H' that is widely used in biodiversity studies despite its well-known shortcomings (Shah et al., 2003). There were no previous studies about diversity indices of staphylinids from our agroecosystems that might be referred to difficult identification of staphylinids (Eyre, 1998; Shah et al., 2003). Usually values ranged between 1.5 to 3.5 and rarely exceeded 4.5 (Magurran, 1988; Marquez, 2003). Our results are in agreement with the results from both years (2008 and 2009). Evenness $\left(\mathrm{J}^{\prime}\right)$ indicated that the distribution pattern and its value ranged from 0 to 1 (Magurran, 1988; Marquez, 2003). In Ireland, 15 common staphylinid species were found from cereals in pitfall trapping by Good and Giller (1991). In our study, the common staphylinid species, Paederus fuscipes was more abundant in maize and berseem and was collected using pitfall trapping. Possibly, the reason for this may be due to more humid microclimate and to higher crop densities (Basedow, 1994). There was less difference in ShannonWiener index values between the two years. Our findings are consistent with other researchers who have indicated greater abundances with organic systems but no differences between organic and conventional annual farming systems using the Shannon-Wiener index (Hokkanen and Holopainen, 1986; Clark, 1999). All 26 species were present in cropped areas, while only 17 species were found in the forest areas. This difference in species can be attributed to biotic factors, e.g. different crops, and abiotic factors, e.g. temperature, relative humidity, and soil moisture.

Effect of abiotic factors on rove beetles: The results indicated that there was a positive correlation between decaying organic matter, especially dung, soil moisture contents, and staphylinid population. There was a difference between staphylinid communities in cropped area and in the forest. This difference in species composition was due to biotic factors such as different crops and abiotic factors such as temperature, relative humidity and soil moisture contents. These results are in agreement with those of other researchers (Sanderson et al., 1995; Koivula et al., 1999; Schiegg, 2000; Judas et al., 2002; Kehler et al., 2004). Seasons also affected the staphylinid population, e.g. rainfall. Months receiving more rainfall (July-August) normally showed maximum staphylinid abundance. Months with less rain fall or with no rain fall indicated lower abundance, i.e. in May, September or October. There was normally a maximum abundance and a maximum diversity during July-August. These results are consistent with the results of other scientists (Koller et al., 2002). It was clear from our results that most species were not strongly associated with a particular season (Elliott et al., 2006).

Conclusion: From this study, we conclude that biotic (soft bodied insects, crop type) and abiotic (temperature, soil moisture contents, rainfall, type of locality) factors significantly affected the activity of rove beetles. Abundance and diversity of rove beetles were found to be affected by different seasons and months of the year. Months receiving more rainfall (July-August) normally showed maximum staphylinid abundance.

\section{REFERENCES}

Abbas, M.N., R. Iqbal, M. Hussain, S. Kausar and R. Saleem. 2014. Predator-prey ratios of macroinvertebrates in wheat and sugarcane agroecosystems. J. Glob. Innov. Agric. Soc. Sci. 2:23-27.

Abdullah, M. and N.N. Qadri. 1968. The Micropeplidae and Staphylinidae (I. Steninae, Euaesthetinae and Oxyporinae), Coleoptera of Pakistan with descriptions of a new tribe, genus and three species from Karachi. Pak. J. Sci. Ind. Res. 11:303-312.

Abdullah, M. and N.N. Qadri. 1970. The Staphylindiae [sic], Coleoptera of Pakistan. Part III. A key to the genera and species of the Piestinae, Osoriinae, Pseudopsinae and Oxytelinae, with descriptions of new genera, subgenera 
and species from Karachi. Pak. J. Sci. Ind. Res. 13:114131.

Apigian, K., D.L. Dahlsten and S.L. Stephens. 2006. Biodiversity of Coleoptera and the importance of habitat structural features in a Sierra Nevada mixed-conifer forest. Environ. Entomol. 35:964-975.

Basedow, T. 1994. Phenology and egg production in Agonum dorsal and Pterostichusmeanarius (Col., Carabidae) in winter wheat fields of different growing intensity in northern Germany; p.101-107. In: K. Desender, M. Dufrene, M. Loreau, M.L. Luff and J.P. Maelfait (eds.), Carabid Beetles: Ecology and Evolution. Kluwer Academic Publishers, Dordrecht.

Cameron, M. 1930. The Fauna of British India including Ceylon and Burma.Coleoptera, Staphylinidae, Vol. I, II, III, IV. Taylor and Francis, London.

Chung, A.Y.C., P. Eggleton, M.R. Speight, P.M. Hammond and V.K. Chey. 2000. The diversity of beetles assemblages in different habitat types in Sabah, Malaysia. Bull. Entomol. Res. 90:475-496.

Clark, M.S. 1999. Ground beetle abundance and community composition in conventional and organic tomato systems of California's Central Valley. Appl. Soil. Ecol. 11:199206.

Coiffait, H. 1982. Staphylinides (Col.) de la régionhimalayenne et de l'Inde (I. Xantholininae, Staphylininae et Paederinae). Entomol. Basilien 7:231302.

Coiffait, H. 1984. Coléoptèresstaphylinides de la régionpaléarctiqueoccidentale III. Sous famillePaederinae, TribuPaederini 2. Sous familleEuaesthetinae. Nouv. Rev. Entomol. 8:1-424.

Collins, K.L., N.D. Boatman, A. Wilcox, J.M. Holland and K. Chaney. 2002. Influence of beetle banks on cereal aphid predation in winter wheat. Agric. Ecosyst. Environ. 93:337-350.

Coombes, D.S. and N.W. Sotherton. 1986. The dispersal and distribution of polyphagous predatory Coleoptera in cereals. Ann. Appl. Biol.108:461-474.

Derunkov, A. 2007. Species diversity of staphylinidae in the Neman River bason in Belarus. 22 $2^{\text {nd }}$ International Meeting on Biology and systematics of staphylinidae [Abstracts].

Dritschilo, W. and D. Wanner. 1980. Ground beetle abundance in organic and conventional corn fields. Environ. Entom. 9:629-631.

Dritschilo, W. and T.L. Erwin. 1982. Responses in abundance and diversity of cornfield beetle communities to difference in farm practices. Ecology. 63:900-904.

Elliott, N.C., F.A. Tao, K.L. Giles, T.A. Royer, M.H. Greenstone and K.A. Shufran. 2006. First quantitative study of rove beetles in Oklahoma winter wheat fields. BioControl. 51:79-87.

Eyre, M.D. 1998. Invertebrates and the environment: a time for reassessment? Antenna 22:63-70.

Forsyth, A. and J. Alcock. 1990. Female mimicry and resource defense polygyny by males of a tropical rove beetle Leistotrophus versicolor (Coleoptera: Staphylinidae). Behav. Ecol. Sociobiol. 26:325-330.

Fournet, S., J.O. Stapel, N. Kacem, J.P. Nenon and E. Brunel. 2000. Life history comparison between two competitive Aleochara species in the cabbage root fly Delia radicum: Implications for their use in biological control. Ent. Exp. Appl. 96:205-211.

Frank, J.H. and M.C. Thomas. 2002. Featured Creatures. Available online http://creatures.ifas.ufl.edu/misc/beetles/rove_beetles

Garcia, C. and R.P. Chacon de ullea. 2005. Rove beetles (Coleoptera; Staphylinidae) in dry forest fragments of the Cauca river valley. Rev. Col. Entomol. 31:43-50.

Good, J.A. and P.S. Giller. 1991. The effect of cereal and grass management on staphylinid (Coleoptera) assemblages in South West Ireland. J. Appl. Eco. 28:810826.

Herman, L.H. 2001.Catalog of the Staphylinidae (Insecta: Coleoptera) 1758 to the end of the second millennium.Bull. Ame. Muse. Nat. Hist. 264:1-83.

Hlavác, P. 2006. Pakistatyrusatergen. et sp. n. of Tyrina (Coleoptera, Staphylinidae: Pselaphinae) from Pakistan. Nat. Croat. 15:171-175.

Hokkanen, H. and J.K. Holopainen. 1986. Carabid species and activity densities in biologically and conventionally managed cabbage fields.J. Appl. Entomol. 102:353-363.

Huacuja, A.H. 1982. Analisis de la fauna de coleopterosStaphylinidaesaprofilos de Zacualtipan, Hidalgo. Tesis Professional, Fac. De Ciencias, UNAM. Mexico.

Judas, M., K. Dornieden and U. Strothmann. 2002.Distribution of carabid beetle species at the landscape level. J. Biogeogr. 29:491-508.

Kehler, D., S. Bondrup-Nielson and C. Corkum. 2004.Beetle diversity associated with forest structure including deadwood in softwood and hardwood stands in Nova Scotia. Proc. N. S. Inst. Sci. 42:227-239.

Kempton, R.A. 1979. Structure of species abundance and measurement of diversity. Biometrics 35:307-322.

Koivula, M., P. Punttila, Y. Haila and J. Niemela. 1999. Leaf litter and the small-scale distribution of carabid beetles (Coleoptera, Carabidae) in the boreal forest. Ecology 22:424-435.

Koller, W.W., G. Alberto, R.R. Sergio and M. Julio. 2002. Staphylinidae (Coleoptera) associated to cattle dung in Campo Grande, MS, Brazil. Neotr. Ento. 31:641-645.

Kreme, C., R.K. Colwell, T.L. Erwin, D.D. Murphy, R.F. Noss and M.A. Sanjayan. 1993.Terrestrial arthropod assemblages: their use in conservation planning. Conserv. Biol. 7:796-808.

Kromp, B. and K.H. Steinberger. 1992. Grassy field margins and arthropod diversity: a case study on ground beetles and spiders in eastern Austria. Agric. Ecosys. Environ. 40:71-93.

Leschen, R.A.B. and R.T. Allen. 1988. Immature stages, life histories and feeding mechanisms of three Oxyporussp. 
(Coleoptera: Staphylinidae: Oxyporinae). Coleopt. Bull. 42:321-333.

Lobl, I. 1986.Contribution à la connaissance des Scaphidiidae (Coleoptera) du nord-ouest de l'Inde et du Pakistan.Rev. Sui. De Zool. 93:341-367.

Lubke, M. 1991. Activity and population density of epigeal arthropods in fields of winter wheat. IOBC/WPRS Bull. 14:140-144.

Ludwig, J.A. and J.F. Reynolds. 1988. Statistical Ecology: a primer on Methods and Computing. Wiley Press, New York.

Magurran, A.E. 1988. Ecological diversity and its measurement. Croom Helm, London, Great Britain.

Márquez, L.J. 2003. Ecological patterns in necrophilous Staphylinidae (Insecta: Coleóptera) from Tlayacapan, Morelos, México. ActaZool. Mex. 89:69-83.

Nasir, S. 2011. Biodiversity of staphylinids of the Punjab, Pakistan. Ph.D. Diss., Dept. Entomol., Univ. Agric., Faisalabad, Pakistan.

Nasir, S. and W. Akram. 2012. Study of Bionomics of Skirt and Blouse beetle (Paederusfuscipes Curtis), 1826 (Coleoptera: Staphylinidae, Paederinae). Pak. J. Agri. Sci. 49:447-450.

Nasir, S., W. Akram, R.R. Khan, M. Arshad and I. Nasir. 2015. Paederus beetles: the agent of human dermititis. J. Venom. Anim. Toxins incl. Trop. Dis. 21:5.

Newton, A.F.Jr.1984. Mycophagy in Staphylinoidea (Coleoptera). Fungus/Insect Relationships; p.302-353. In: Q. Wheeler and M. Blackwell (eds.), Perspectives in Ecology and Evolution. Columbia University Press, New York.

Newton, A.F.Jr.1990. Staphylinidae (adults) and Staphylinidae (larvae); p.1137-1174. In: D.L. Dindal (ed.), Soil biology guide. Jhon Wiley and Sons, New York.

Nikbakhtzadeh, M.R. and S. Tirgari. 2008. Medically important beetles (Insecta: Coleoptera) of Iran. J. Venom. Anim. Toxins incl. Trop. Dis. 14:597-618.

Pace, R. 1986. Aleocharinaeriportatedall'Himalaya dal Prof. Franz. Parte II. (Coleoptera, Staphylinidae).Nouv. Rev. d'Ent. 3:81-97.

Pielou, E.C. 1984. The Interpretation of Ecological Data, Willey, New York, USA.

Purtauf, T., J. Dauber and V. Wolters. 2005. The response of carabids to landscape simplification differs between trophic groups. Oecologia 142:458-464.

Qadir, S.N.R., N. Raza and S.B. Rehman. 2006. Paederus dermatitis In Sierra Leone. Dermatology Online J. 12:9.

Rehman, K.A. and M.A. Ghani. 1941. Staphylinidae from Lyallpur. p. 202-203. Proceedings $28^{\text {th }}$ Ind. Sc. Cong. part III. Abstracts-Banaras.
Ruiz-Lizarraga, G. 1993. Contribution aicinocimiento de losStaphylinidae (Coleoptera) necrofilos de Acahuizotla Guerrero. Tesis professional, Fac. De Ciencias, UNAM Mexico.

Sanderson, R.A., S.P. Rushton, A.J. Cherrill and J.P. Byrne. 1995.Soil, vegetation, and space: an analysis of their effects on the invertebrate communities of a moorland in north-east England. J. Appl. Ecol. 32:506-518.

Scheerpeltz, O. 1960. Die von Dr. Chr. LindemanngelegentlichihrerReise 1955/56 in WestpakistanaufgesammeltenStaphyliniden (Col.). Opuscula Zool. Münc. 51:1-7.

Schiegg, K. 2000.Effects of dead wood volume and connectivity on saproxylic insect species diversity. Ecosci. 7:290-298.

Shafi, M. 1957. Staphylinidae (Coleoptera) of Lyallpur. Master Diss., Dept. Zool., Univ. Punjab, Pakistan.

Shah, P.A., D.R. Brooks, J.E. Ashby, J.N. Perry and I.P. Woiwod. 2003. Diversity and abundance of the coleopteran fauna from organic and conventional management systems in Southern England. Agric. Forest Ent. 5:51-60.

Shannon, C.E. and W. Wiener. 1949. The mathematical theory of communication. University of Illinois Press, Urbana.

Silveira-Neto, S., O. Nakano, D. Barbin and N.A.V. Nova. 1976. Manual de ecologia de insetos. São Paulo, CERES.

Smetana, A. 2004. Family StaphylinidaeLatreille, 1802 [except Pselaphinae and Scaphidiinae]; p.237-272, 329495, 505-698. In: I. Löbl and A. Smetana (eds.), Catalogue of Palaearctic Coleoptera, Vol. 2. Hydrophiloidea-Histeroidea-Staphylinoidea. Apollo Books, Stenstrup.

Somerset, E.J. 1961. "Spider Lick" an epidemic ophthalmodermatozoosis due to beetles of the genus Paederus. Brit. J. Ophthal. 45:395.

Sotherton, N.W. 1985. The distribution and abundance of predatory Coleoptera over wintering in field boundaries. Ann. Appl. Biol. 106:17-21.

Taylor, L.R. 1978. Bates, Williams, Hutchison- a variety of diversities, pp.1-18. In: L.A. Mound and N. Waloff (eds.), Diversity of Insect Fauna: 9th Symp. R. Entomol. Soc. Blackwell, Oxford.

Taylor, L.R., R.A. Kempton and I.P. Woiwod. 1976. Diversity statistics and the log-series model. J. Anim. Ecol. 45:255-271.

Tonhasca, A. 1993. Beetle assemblage under diversified agroecosystems. Entomol. Exp. Appl. 68:279-285.

Wyatt, T. 1993. Submarine beetles: when the tide comes in, they batten down the hatches. Nat. Hist. 102:6, 8-9. 